\title{
Effect of Bacillus cereus Enzymes on the Milk Quality following Ultra High Temperature Processing
}

\author{
B. JANŠTOVÁ, M. DRAČKOVÁ, L. VORLOVÁ \\ Department of Milk Hygiene and Technology, Faculty of Veterinary Hygiene and Ecology \\ University of Veterinary and Pharmaceutical Sciences Brno
}

Received April 5, 2005

Accepted June 30, 2006

\begin{abstract}
Janštová B., M. Dračková, L.Vorlová: Effect of Bacillus cereus Enzymes on the Milk Quality following Ultra High Temperature Processing. Acta Vet Brno 2006, 75: 601-609.

Using a model case of contamination of long-life semi-skimmed milk with the spores of six $B$. cereus strains, isolated from the farm environment and raw milk, proteolysis was monitored by measuring changes in protein content by infra-red spectroscopy; free tyrosine was measured by the Lowry method according to Juffs, and the reduction in casein fractions by SDS-PAGE. Lipolysis was monitored by the dilution extractive method. At a storage temperature of $4{ }^{\circ} \mathrm{C}$ for 4 months no enzyme processes were observed, whereas at a storage temperature of $24{ }^{\circ} \mathrm{C}$ a marked enzyme activity was found during maximum 3 weeks as well as sensory changes of UHT milk. After three weeks of storage, a reduction in protein content from $34.55 \mathrm{~g} \cdot 1^{-1}$ milk to $29.46 \pm 2.00 \mathrm{~g} \cdot 1^{-1} \mathrm{milk}$, and a reduction in the free tyrosine from 0.65 to $2.13 \pm 0.28 \mathrm{mg} \cdot \mathrm{ml}^{-1}$ was found, as well as increased molar contents of free fatty acids (FFA) from 41.97 to $1617.22 \pm 68.17 \mathrm{mmol} \cdot \mathrm{kg}^{-1} \mathrm{milk}$ fat. After six days of storage, $\alpha$-casein, $\beta$-casein and $\kappa$-casein dropped to $69 \pm 10 \%, 56 \pm 16 \%$ and $43 \pm 10 \%$, respectively. Majority of changes in UHT milk depended on the B. cereus strain used, initial microbial counts and the method of heat inactivation of spores.
\end{abstract}

Bacillus cereus, spores, proteolysis, casein, lipolysis

Bacillus spp. are questionable components of raw milk microflora because of a difficult removal of their spores due to thermal resistance. They are significant contaminants of fresh milk in terms of hygiene, technology, and in the case of B. cereus of health, too. Brown (2000) described Bacillus spp. as microorganisms that cause significant economic losses.

The spores of Bacillus spp. commonly occur in the barn environment and represent secondary contamination of milk during milking. The most frequently isolated Bacillus species from raw milk are B. licheniformis and B. cereus (Crielly et al. 1994), whereas other bacilli occur less frequently (Lukášová et al. 2001; Vyletělová et al. 2001). Many researchers attribute the changes in Bacillus species distribution to seasonal influences (Sutherland and Murdock 1994). On the contrary, Lukášová et al. (2001) did not confirm the effect of seasonal factors on the incidence of Bacillus spp. in milk. Christiansson et al. (1999) pointed out an increased contamination of milk with B. cereus spores during the grazing season, associated with a higher incidence of spores in milk. On farms with good hygiene management, the spore counts in milk should lie within $0.2-10^{4} \cdot 1^{-1}$ (Harmon and Kautter 1991). Bacillus spp. spores may occur also in UHT milk, as reported by B ahout (2000) who found the spores in $18.3 \%$ samples investigated at a count of $2.6 \times 10^{2} \cdot \mathrm{ml}^{-1}$ and noted a presence of $B$. cereus. Vyletělová (2001) monitored by ribotyping the incidence of $B$. cereus in milk, from raw milk to the final product (UHT milk). She assumed milk was contaminated either at the farm or recontaminated during processing.

B. cereus is regarded as a psychrotrophic species. In 1998, B. weihenstephanensis was identified, previously designated as $B$. cereus, based on its ability to grow at $4-6.5^{\circ} \mathrm{C}$.

Address for correspondence:

MVDr. Bohumíra Janštová, Ph.D.

Department of Milk Hygiene and Technology

University of Veterinary and Pharmaceutical Sciences

Palackého 1/3, 61242 Brno, Czech Republic
Phone: +420541562712

Fax: +420 541562711

E-mail: janstovab@vfu.cz

http://www.vfu.cz/acta-vet/actavet.htm 
Silveira et al. (1999) examined milk contaminated with $2.7 \times 10^{4}$ spores per $1 \mathrm{ml}$, and found 80 psychrotrophic strains out of 180 investigated.

An important property of Bacillus spp. is the ability of the vegetative cells to produce thermostabile extracellular enzymes after proliferation (Meer et al. 1991; Ipsen et al. 2000) that by their proteolytic and lipolytic activity affect the nutritional and sensory properties even if viable bacteria are not present (B oor et al. 1998).

Johnston and Bruce (1982) examined 100 samples and found 19 B. cereus strains. They demonstrated a marked biochemical activity of Bacillus spp., i.e. casein hydrolysis in $84 \%$ samples, lipolysis in 52\% samples. In $77 \%$ samples lecitinase-positive strains were found.

Casein proteolysis is the most significant part of milk protein proteolysis. An amount of $10^{4}-10^{8}$ bacterial cells in $1 \mathrm{ml}$ milk are required to influence casein contents ( Marth and Steele 1998). From milk proteins, $\kappa$-casein is hydrolyzed preferably. During 7 days of storage at $20{ }^{\circ} \mathrm{C}$ all the $\kappa$-casein is converted to para- $\kappa$-casein, $\beta$-casein content is reduced by $70 \%$. The longest lasting stability is shown by $\alpha$-casein, its loss is minimum (Dalglies h 1990). As compared with $\kappa$-casein fractions, $\alpha$-lactalbumin and $\beta$-lactoglobulin are resistant to degradation ( Swais good 1993; Madsen and Quist 1997).

Unlike milk lipases, microbial lipases are thermoresistant and remain active even after the heating or UHT treatment. They may cause the development of rancid taste and smell of milk, thus contributing to the impairment of a product. Lipase action causes difficulties in marketing UHT products if lipases are present in raw material and their activity is maintained in the UHT product (Champagne et al. 1994).

Enzyme action causes many defects of milk and dairy products such as sweet clotting, colour and odour defects. Special attention is paid to gelation of UHT milk (Datta and Deeth 2001; McMahon 1996). Defects were detected when microbial concentrations of $5 \times 10^{5}-10^{7} \mathrm{CFU} \cdot \mathrm{ml}^{-1}$ were achieved (Vyletělová et al. 2000; Marth and Steele 1998). Matta and Punj (1999) reported odour defects such as fruity, yeasty, dirty, rotten and bitter smell in association with an incidence of $48 \%$ lipolytic Bacillus strains in raw milk samples.

\section{Materials and Methods}

Strains from the collection at the Department of Milk Hygiene and Technology were used in the trials. These included 6 strains of Bacillus cereus, isolated from the farm environment and raw milk. The isolated strains were identified by Lukášová et al. (2005). As cultivation medium to be contaminated with spores durable whole milk from the market network was used. The UHT milk originated from the same batch.

Milk samples under investigation were inoculated with spore suspensions of Bacillus cereus without heat inactivation, at such doses to achieve concentrations of spores of 102, 101, < 101 in $1 \mathrm{ml}$ UHT milk. Furthermore, suspensions of spores were inoculated, exposed to $100{ }^{\circ} \mathrm{C}$ for 10 minutes in water bath and to $135^{\circ} \mathrm{C}$ for 5 seconds in glycerol bath, at the same doses. Thermo-inactivation of spores suspension $(5 \mathrm{ml})$ was performed after heating at $70{ }^{\circ} \mathrm{C}$. Temperature was controlled by thermometer. The complete inactivation of B. cereus spores was performed after heating to $100{ }^{\circ} \mathrm{C}$ for $10 \mathrm{~min}$ and $135^{\circ} \mathrm{C}$ for $5 \mathrm{~s}$. Milk samples were kept in sealed sterile glass containers at $24{ }^{\circ} \mathrm{C}$ in the thermostat, and at $4{ }^{\circ} \mathrm{C}$ in the refrigerator. The analysis was performed at 1 -week intervals for 3 weeks. All samples were analysed in triplicate.

Protein contents were measured by infra-red spectroscopy MIR, using the device MilkoScan 104 with multidetection application (A/S N. Foss Electric, Denmark). The instrument was calibrated by UHT milk. For the sample analysis, potassium dichromate $\left(\mathrm{K}_{2} \mathrm{Cr}_{2} \mathrm{O}_{7}\right)$ was used at a dose of $0.6 \mathrm{~g} \cdot \mathrm{l}^{-1}$ milk. As the second method of bacterial proteolysis detection by measuring free tyrosine levels, the Lowry method according to Juffs (1973) was used with Folin-Ciocalteu phenol reagent, resulting, after the reaction with released tyrosine, in blue colour of solution, measured by the Helios a spectrophotometer (Unicam, England, UK) .

For the monitoring of casein fraction, spore suspensions of $B$. cereus, both non-inactivated with heat and heat inactivated $\left(100^{\circ} \mathrm{C} / 10 \mathrm{~min}\right)$, at a concentration of $10^{1} \cdot \mathrm{ml}^{-1}$, were used. The samples were stored at $24^{\circ} \mathrm{C}$ for 6 days and at $4{ }^{\circ} \mathrm{C}$ for 4 months. Casein was isolated and lyophilized according a method of López-Fandino et al. (1993). The lyophilised casein was solved in Tris-HCl (pH 8.8) and sample buffer was added $(2.4 \mathrm{ml} \mathrm{Tris-} \mathrm{HCl} \mathrm{pH}$ 6.8, $2 \mathrm{ml} \mathrm{10 \%} \mathrm{SDS} \mathrm{(w/v),} 1 \mathrm{ml}$ glycerol, $0.5 \mathrm{ml}$ 2-mercapthoethanol, $4.0 \mathrm{ml}$ distilled water, $0.1 \mathrm{ml}$ bromophenol blue) at the ratio of 1:4. The samples were boiled for $2 \mathrm{~min}$. PAGE in the presence of sodium dodecyl sulphate (SDS-PAGE) was performed by the methods of Laemmli (1970). To separate casein fraction, separation gels 
were used $(15 \% \mathrm{~T}, 2.6 \% \mathrm{C})$ and concentrating gels $(3 \% \mathrm{~T}, 2.6 \% \mathrm{C})$, with Mini-Protean III Cell Electrophoresis apparatus (Bio-Rad Laboratories, Richmond, CA). Separation buffer (30.3 g Tris, $144 \mathrm{~g}$ glycine, $10 \mathrm{~g}$ SDS completed up to 1 litre with distilled water) was used for migration, diluted at the ratio of 1:9 with distilled water. Electrophoresis took place at $110 \mathrm{~V}$ at room temperature. Gels were stained with Commassie Brilliant Blue R-250 and evaluated by computer software Image Quant 5.0 (Molecular Dynamics, USA). Quantification was based on pixel density (converted to \%) of different band areas of casein fractions. Values of pixels were always related to the standard value (milk without Bacillus cereus). Repeatability of the method was RSD 10.

For the detection and quantification of lipolysis, an extraction and titration method of determination of molar FFA contents according to the standard ČSN 570533 (1998) was used. Molar contents of FFA were given in $\mathrm{mmol} \cdot \mathrm{kg}^{-1}$ milk fat.

Because there was a possibility to compare the growth dynamics of microbial counts and changes in variables under study, bacteriological analyses of milk samples were carried out, i.e. the determination of total counts of spore-forming microorganisms. The cultivation media Plate Count Agar was used (HiMedia, India). During the sample collection the sensoric evaluation (colour, coagulum, odour) was carried out.

Values of protein, tyrosine, FFA and casein contents at $4{ }^{\circ} \mathrm{C}$ after thermic inactivation are not introduced because no changes were found.

Significance at $p<0.01$ and $p<0.05$ was evaluated for different variables by the Statistical and Graphical system STAT Plus (Matoušková et al. 1992). Data were processed by the analysis of dispersion and for subsequent testing the Scheffe method of contrasts and Tuckey test were used. To achieve correctness of results, the Box-Cox transformation was used before the analysis of dispersion because the requirements of normal basic distribution were met. For this, the Bartlett test was used.

\section{Results and Discussion}

An increase in the number of microorganisms was observed during 3 weeks (Table 1). In the $3^{\text {rd }}$ week amounts of $10^{8} \cdot \mathrm{ml}^{-1} \mathrm{CFU}$ (in samples with higher initial spores count) and $10^{5} \cdot \mathrm{ml}^{-1} \mathrm{CFU}$ (in samples with initial spore concentration of $<10^{1} \cdot \mathrm{ml}^{-1}$ ) were found. No growth of microorganism was observed in samples stored at $4{ }^{\circ} \mathrm{C}$.

Table 1. Mean count of microorganisms $\left(\mathrm{CFU} \cdot \mathrm{ml}^{-1}\right)$ in UHT milk with $B$. cereus spores during the storage (week) at $24{ }^{\circ} \mathrm{C}$ and $4{ }^{\circ} \mathrm{C}$

\begin{tabular}{|c|c|c|c|c|c|c|}
\hline \multirow{3}{*}{$\begin{array}{c}\text { Storage } \\
\text { (week) }\end{array}$} & \multicolumn{7}{|c|}{ Temperature $\left({ }^{\circ} \mathrm{C}\right)$} \\
\cline { 2 - 7 } & \multicolumn{7}{|c|}{24} & \multicolumn{7}{c|}{4} & \multicolumn{1}{c|}{} \\
\cline { 2 - 7 } & $10^{2}$ & $10^{1}$ & $<10^{1}$ & $10^{2}$ & $10^{1}$ & $<10^{1}$ \\
\hline 0 & $5 \cdot 10^{2}$ & $3 \cdot 10^{1}$ & 3 & $5 \cdot 10^{2}$ & $3 \cdot 10^{1}$ & 3 \\
\hline 1 & $3 \cdot 10^{6}$ & $2 \cdot 10^{5}$ & $2 \cdot 10^{4}$ & $6 \cdot 10^{2}$ & $3 \cdot 10^{1}$ & 2 \\
\hline 2 & $3 \cdot 10^{7}$ & $4 \cdot 10^{7}$ & $1 \cdot 10^{5}$ & $8 \cdot 10^{2}$ & $5 \cdot 10^{1}$ & 6 \\
\hline 3 & $3 \cdot 10^{8}$ & $2 \cdot 10^{8}$ & $6 \cdot 10^{5}$ & $5 \cdot 10^{2}$ & $4 \cdot 10^{1}$ & 0 \\
\hline
\end{tabular}

A decrease in protein content, due to the action of proteolytic enzymes, was observed only in the samples inoculated with thermically non-inactivated spores stored at $24{ }^{\circ} \mathrm{C}$, and corresponded with an increase in bacterial counts. No proteolysis was found in samples with B. cereus spores inactivated at $100{ }^{\circ} \mathrm{C}$ for $10 \mathrm{~min}$ and $135^{\circ} \mathrm{C}$ for $5 \mathrm{~s}$. During storage at $4{ }^{\circ} \mathrm{C}$ for 3 months growth of microorganisms was not monitored and changes in the protein content were not obtained. A more pronounced proteolysis was found in the samples with higher initial counts of spores in milk, a lower proteolysis was observed in the samples containing a few spores.

A marked reduction of the initial protein content $\left(34.55 \mathrm{~g} \cdot \mathrm{l}^{-1}\right)$ milk was observed for all the strains under investigation in the milk samples containing B. cereus spores. Table 2

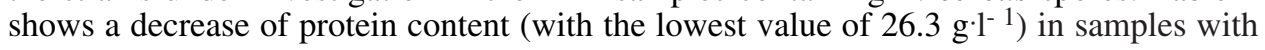
spores of individual B. cereus strains. As Table 3 shows, the average values after storage for 1,2 , and 3 weeks were $32.64-30.36-29.46 \mathrm{~g}^{-1}$ (initial concentration of spores was $10^{2} \cdot \mathrm{ml}^{-1}$ ), $33.52-50.48-29.76 \mathrm{~g}^{-1}$ (initial concentration of spores was $10^{1} \cdot \mathrm{ml}^{-1}$ ) and $33.96-32.34$ 
Table 2. Protein contents $\left(\mathrm{g} \cdot \mathrm{l}^{-1}\right)$ in UHT milk with B. cereus spores during the storage (week) at $24{ }^{\circ} \mathrm{C}$

\begin{tabular}{|c|c|c|c|c|}
\hline Strain & $\begin{array}{c}\text { Storage } \\
\text { (week) }\end{array}$ & $10^{2}$ & Initial spore counts in $1 \mathrm{ml}$ milk \\
\hline \multicolumn{5}{|c|}{ Initial protein level: $34.55 \mathrm{~g} \cdot \mathrm{l}^{-1}$} \\
\hline \\
\hline 1 & 1 & 33.1 & 33.5 & $<10^{1}$ \\
\hline & 2 & 30.7 & 31.9 & 33.2 \\
\hline & 3 & 29.2 & 30.0 & 32.5 \\
\hline & 1 & 33.3 & 34.5 & 33.2 \\
\hline & 2 & 30.1 & 30.1 & 32.3 \\
\hline & 3 & 29.5 & 29.5 & 29.9 \\
\hline 3 & 1 & 30.9 & 31.0 & 31.2 \\
\hline & 2 & 27.2 & 26.9 & 30.6 \\
\hline & 3 & 26.3 & 26.2 & 28.2 \\
\hline & 1 & 33.0 & 32.8 & 33.8 \\
\hline & 2 & 31.7 & 31.0 & 33.4 \\
\hline & 3 & 30.8 & 31.7 & 34.0 \\
\hline 5 & 1 & 32.9 & 33.8 & 33.5 \\
\hline & 2 & 32.1 & 32.5 & 32.5 \\
\hline & 3 & 31.5 & 31.4 & 31.7 \\
\hline
\end{tabular}

Table 3. Mean protein contents $\left(\mathrm{g} \cdot \mathrm{l}^{-1}\right)$ in samples with B. cereus spores found during the storage (weeks) at $24^{\circ} \mathrm{C}$

\begin{tabular}{|l|c|c|c|c|}
\hline \multirow{2}{*}{$\begin{array}{l}\text { Inactivation of } \\
\text { spores }\end{array}$} & \multirow{2}{*}{ Week } & \multicolumn{3}{|c|}{ Initial spore counts in $1 \mathrm{ml}$ milk } \\
\cline { 3 - 5 } & & $10^{2} \pm \mathrm{SD}$ & $10^{1} \pm \mathrm{SD}$ & $<10^{1} \pm \mathrm{SD}$ \\
\hline \multirow{3}{*}{$\begin{array}{l}\text { No heat } \\
\text { inactivation }\end{array}$} & 1 & $32.64 \pm 0.98$ & $33.52 \pm 1.33$ & $33.96 \pm 1.03$ \\
\cline { 2 - 5 } & 2 & $30.36 \pm 1.94$ & $30.48 \pm 2.20$ & $32.34 \pm 1.06$ \\
\cline { 2 - 5 } & 3 & $29.46 \pm 2.00$ & $29.76 \pm 2.14$ & $31.26 \pm 2.26$ \\
\hline \multirow{3}{*}{$100^{\circ} \mathrm{C} 10$ min } & 1 & $34.40 \pm 0.06$ & $34.40 \pm 0.06$ & $34.50 \pm 0.00$ \\
\cline { 2 - 5 } & 2 & $34.40 \pm 0.00$ & $34.40 \pm 0.00$ & $34.40 \pm 0.00$ \\
\cline { 2 - 5 } & 3 & $34.30 \pm 0.00$ & $34.30 \pm 0.00$ & $34.30 \pm 0.00$ \\
\hline $135^{\circ} \mathrm{C} 5 \mathrm{~s}$ & 1 & $34.45 \pm 0.07$ & $34.35 \pm 0.07$ & $34.45 \pm 0.07$ \\
\cline { 2 - 5 } & 2 & $34.45 \pm 0.07$ & $34.40 \pm 0.00$ & $34.40 \pm 0.00$ \\
\cline { 2 - 5 } & 3 & $34.35 \pm 0.07$ & $34.35 \pm 0.07$ & $34.45 \pm 0.07$ \\
\hline
\end{tabular}

a $31.26 \mathrm{~g} \cdot \mathrm{l}^{-1}$ (initial concentration of spores was $<10^{1} \cdot \mathrm{ml}^{-1}$ ). In the $1^{\text {st }}$ week, protein contents were significantly higher $(p<0.05)$ than in the $3^{\text {rd }}$ week.

Kelly and Foley (1997) also used the apparatus MilcoScan to measure protein cleavage. They found protein contents ranging from 3.13 to $3.30 \%$. The reductions in protein contents they found are similar to those observed in this study, but it is difficult to compare the values with our results because of different experimental conditions and different bacterial enzyme producers used in the trials. A reduction in protein contents in milk due to lytic enzyme activity was studied also by Corzo et al. (1994), Recio et al. (2000), Zhao et al. (1998), Madsen and Qvist (1997), but they used other methods.

Results of free tyrosine content measurements are listed in Table 4. There was a marked proteolytic activity observed in $B$. cereus during storage, and an increase in free tyrosine content from the initial value of $0.65 \mathrm{mg} \cdot \mathrm{ml}^{-1}$ to $2.13 \pm 0.28$ and $2.09 \pm 0.19 \mathrm{mg} \cdot \mathrm{ml}^{-1}$ at a higher concentration of spores and to $1.66 \pm 0.25 \mathrm{mg} \cdot \mathrm{ml}^{-1}$ at a concentration $<10^{1} \cdot \mathrm{ml}^{-1}$. Lukášová (1985) studied proteolytic activity of psychrotrophic microorganisms in milk and found increased free tyrosine, up to $1.21 \mathrm{mg} \cdot \mathrm{ml}^{-1}$ with $10^{8} \mathrm{CFU} \cdot \mathrm{ml}^{-1}$, which corresponds 
Table 4. Mean free tyrosine contents $\left(\mathrm{mg} \cdot \mathrm{ml}^{-1}\right)$ in UHT milk with B. cereus spores during the storage (days) at $24^{\circ} \mathrm{C}$

\begin{tabular}{|c|c|c|c|c|c|c|c|c|}
\hline $\begin{array}{c}\text { Initial spore count } \\
\text { in milk }\left(\cdot \mathrm{ml}-^{-}\right)\end{array}$ & \multicolumn{7}{|c|}{ Storage time (days) } \\
\cline { 2 - 9 } & Initial level & 1 & 2 & 3 & 7 & 14 & 21 & 28 \\
\hline $10^{2}$ & $0.65 \pm 0.08$ & $0.69 \pm 0.09$ & $0.97 \pm 0.06$ & $1.18 \pm 0.10$ & $1.42 \pm 0.15$ & $1.66 \pm 0.27$ & $2.01 \pm 0.16$ & $2.13 \pm 0.28$ \\
\hline $10^{1}$ & $0.65 \pm 0.08$ & $0.69 \pm 0.09$ & $0.89 \pm 0,09$ & $1.09 \pm 0.09$ & $1.36 \pm 0.18$ & $1.62 \pm 0.23$ & $1.88 \pm 0.07$ & $2.09 \pm 0.19$ \\
\hline$<10^{1}$ & $0.65 \pm 0.08$ & $0.67 \pm 0.08$ & $0.74 \pm 0.11$ & $0.94 \pm 0.09$ & $1.27 \pm 0.17$ & $1.41 \pm 0.22$ & $1.54 \pm 0.28$ & $1.66 \pm 0.25$ \\
\hline
\end{tabular}

with the values we received with the same bacterial counts. In the $3^{\text {rd }}$ week, free tyrosine was significantly higher $(p<0.05)$ than in the $2^{\text {nd }}$ week, and highly significantly higher $(p<0.01)$ than in the $1^{\text {st }}$ week.

When B. cereus spores had been exposed to temperatures of $100{ }^{\circ} \mathrm{C}$ for $10 \mathrm{~min}$ and $135^{\circ} \mathrm{C}$ for $5 \mathrm{~s}$, no proteolysis was observed in the milk samples because the spores had been destroyed. Microbial enzymes break casein first, before they start breaking whey proteins (López-Fandino et al. 1993). In UHT milk stored at $24{ }^{\circ} \mathrm{C}$, containing non-inactivated B. cereus spores, a marked decrease in all casein fractions was observed. The initial $100 \%$ content of $\alpha$-casein was decreased to $69 \pm 10 \%$ on the $6^{\text {th }}$ day of storage. In addition, decreased $\beta$-casein and $\kappa$-casein contents were noted, $56 \pm 16 \%$ and $43 \pm 10 \%$, respectively (Fig. 1 and Plate V, Fig. 3). We compared changes in different casein fractions and did not find significant differences between $\alpha$ - and $\beta$-casein levels. However, significant differences $(p<0.05)$ and $(p<0.01)$ were found between $\beta$ - and $\kappa$-casein, and $\kappa$ - and $\alpha$ casein contents, respectively.

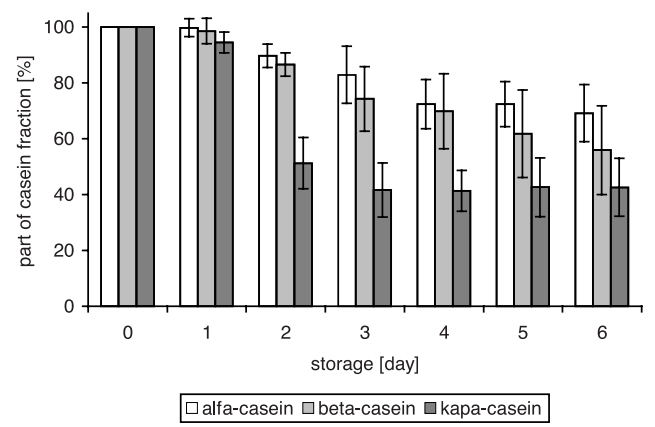

Fig. 1. Proteolytic effects of Bacillus cereus on casein fractions in UHT milk stored at $24{ }^{\circ} \mathrm{C}$

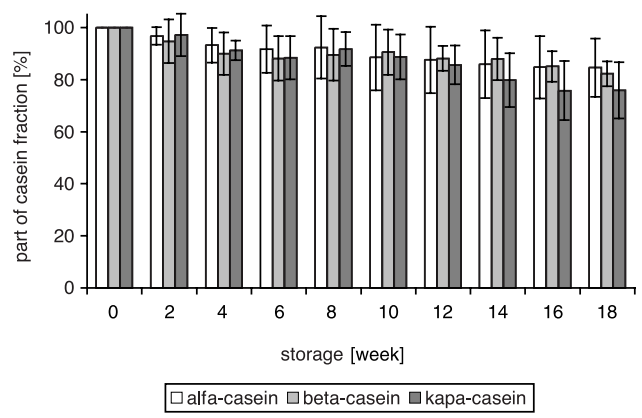

Fig. 2. Proteolytic effects of Bacillus cereus on casein fractions in UHT milk stored at $4{ }^{\circ} \mathrm{C}$ 
In the milk samples inoculated with non-inactivated spores and stored at $4{ }^{\circ} \mathrm{C}$ (Fig. 2), no such great reduction in casein fractions was observed as in the samples stored at $24^{\circ} \mathrm{C}$. After 18 weeks of storage, $\alpha$-casein level was reduced to $85 \pm 11 \%$. $\beta$-casein and $\kappa$-casein contents dropped to $82 \pm 5 \%$ and $76 \pm 11 \%$, respectively. No statistically significant differences were found between reductions in levels of different casein fractions and between control samples and samples with Bacillus cereus.

$B$. cereus spores were inactivated and destroyed by a 10-minute exposure to the temperature of $100{ }^{\circ} \mathrm{C}$, and no statistically significant changes in casein fraction levels were found during storage at $24^{\circ} \mathrm{C}$.

Similar results were obtained by Melachouris and Tuckey (1968) who reported that $\beta$-casein was more readily degraded by $B$. cereus proteases than other casein fractions at $30{ }^{\circ} \mathrm{C}$. Gallagher et al. (1994) studied the effects of B. subtilis protease on casein fractions at an optimum temperature of $40^{\circ} \mathrm{C}$. After 1 hour, $\alpha$-casein was found unchanged, whereas $\beta$-casein was completely hydrolyzed after 40 minutes. Other researchers such as LópezFandino et al. (1993) monitored reductions in contents of casein fractions due to the effect of Pseudomonas fluorescens B52 proteases. The greatest reduction was noted in the $\kappa$-casein fraction, $\alpha$-casein appeared the most stable. Similar results were reported by Is mail et al. (1991) and Dogru et al. (2001). The above-mentioned results imply that a storage temperature has a decisive effect on the degradation rate of casein fractions.

Increased FFA contents were observed only in the samples stored at $24{ }^{\circ} \mathrm{C}$. The changes were observed when levels of $10^{4}-10^{5} \mathrm{CFU} \mathrm{ml}^{-1}$ were reached, maximum CFU counts in the $3^{\text {rd }}$ week of storage were identical in all the strains used, i.e. $10^{8} \cdot \mathrm{ml}^{-1}$.

Marked lipolysis was found in the samples with higher initial contents of inoculated, heat non-inactivated spores in milk, in the samples with few spores a lower degree of lipolysis was found. Mean initial FFA content in milk used in the trial was $41.97 \mathrm{mmol} \cdot \mathrm{kg}^{-1}$ milk fat. In general, B. cereus strains showed a very high lipolytic activity, which is demonstrated by high FFA contents found even in the samples with the lowest initial spore counts. However, marked differences were found between different strains. During three weeks of storage, in the samples with the initial spore count of $10^{2} \cdot \mathrm{ml}^{-1}$, FFA contents of $241.79 \pm 160.48,771.44$ \pm 485.22 and $1617.22 \pm 68.17$ were found, in the samples with lower spore counts, the final values were $1261.18 \pm 31.11$ and $895.00 \pm 13.01 \mathrm{mmol} \cdot \mathrm{kg}^{-1}$ fat (Table 5).

Table 5. Mean FFA contents (mmol $\mathrm{kg}^{-1}$ milk fat) in milk with B. cereus spores during the storage (weeks) at $24{ }^{\circ} \mathrm{C}$

\begin{tabular}{|l|c|c|c|c|}
\hline \multirow{2}{*}{$\begin{array}{l}\text { Inactivation of } \\
\text { spores }\end{array}$} & \multirow{2}{*}{ Week } & \multicolumn{3}{|c|}{ Initial spore counts in $1 \mathrm{ml} \mathrm{milk}$} \\
\cline { 3 - 5 } & & $10^{2} \pm \mathrm{SD}$ & $10^{1} \pm \mathrm{SD}$ & $<10^{1} \pm \mathrm{SD}$ \\
\hline \multirow{3}{*}{$\begin{array}{l}\text { No heat } \\
\text { inactivation }\end{array}$} & 1 & $241.79 \pm 160.48$ & $202.63 \pm 129.53$ & $157.71 \pm 147.84$ \\
\cline { 2 - 5 } & 2 & $771.44 \pm 485.22$ & $838.98 \pm 559.94$ & $701.96 \pm 438.31$ \\
\cline { 2 - 5 } & 3 & $1617.22 \pm 68.17$ & $1261.18 \pm 31.11$ & $895.00 \pm 13.01$ \\
\hline \multirow{3}{*}{$100^{\circ} \mathrm{C} 10 \mathrm{~min}$} & 1 & $42.58 \pm 0.38$ & $43.25 \pm 0.71$ & $43.08 \pm 0.35$ \\
\cline { 2 - 5 } & 2 & $42.62 \pm 0.71$ & $42.15 \pm 1.07$ & $42.42 \pm 1.68$ \\
\cline { 2 - 5 } & 3 & $42.55 \pm 2.11$ & $42.32 \pm 0.98$ & $42.60 \pm 1.25$ \\
\hline $135^{\circ} \mathrm{C} 5 \mathrm{~s}$ & 1 & $43.08 \pm 0.85$ & $42.38 \pm 0.99$ & $42.73 \pm 0.24$ \\
& 2 & $43.32 \pm 0.08$ & $43.03 \pm 0.33$ & $43.07 \pm 0.38$ \\
\cline { 2 - 5 } & 3 & $43.29 \pm 0.20$ & $43.04 \pm 0.05$ & $43.09 \pm 0.03$ \\
\hline
\end{tabular}

After the exposure of B. cereus spores to $100{ }^{\circ} \mathrm{C}$ for $10 \mathrm{~min}$ and $135^{\circ} \mathrm{C}$ for $5 \mathrm{~s}$, no lipolysis in the milk samples was observed because the spores were effectively destroyed. Statistical analyses were focused on determination of significance of differences in FFA contents between different storage times. Samples with non-inactivated spores were evaluated, with 
the initial spore count of $10^{2} \cdot \mathrm{ml}^{-1}$ milk, stored at $24{ }^{\circ} \mathrm{C}$. In the $1^{\text {st }}$ week, FFA contents were significantly $(P<0.01)$ higher than in the $3^{\text {rd }}$ week.

The inactivation of spores by exposing them to $100{ }^{\circ} \mathrm{C}$ for 10 minutes and $135^{\circ} \mathrm{C}$ for 5 minutes was $100 \%$ effective. There was no lipolysis observed in the samples inoculated with the heat treated spores.

Against the standard ČSN 570529 (1995) that lays down a maximum FFA content of $32 \mathrm{mmol} \cdot \mathrm{kg}^{-1}$ in raw milk intended for the dairy and processing, measured by the dilution extractive method, increased FFA levels in UHT milk were found, further increasing due to lipolysis. Vlachos and Litopoulou-Tzanetaki (1985) monitored FFA contents in milk, focusing on contents of different FFAs instead of total FFA amount, therefore results of this study cannot be compared to theirs. However, the results of this study correspond with their finding that there are differences in production of lipolytic enzymes even within one bacterial species. Vallejo-Cordoba et al. (1998) used the method of capillary electrophoresis for the qualitative and quantitative determination of chain FFA and recommend it for the monitoring of milk fat lipolysis because it enables obtaining the results quickly.

In the samples stored at $4{ }^{\circ} \mathrm{C}$ for 3 months there was no increase in microbial counts and no changes in terms of quantity of milk components under investigation, as compared with the initial values.

Monitoring proteolytic and lipolytic activity of microflora in pasteurized milk and the effect of storage temperature was studied also by Burdová et al. (2002) who found that in sufficiently heat-treated milk immediately stored under $4{ }^{\circ} \mathrm{C}$, amounts of lipolytic and proteolytic enzymes produced in a three times longer period of time were not comparable with values found in samples stored at $10{ }^{\circ} \mathrm{C}$ for $2-3$ days. Vyletělová (2002) observed the effect of temperature on the growth of B. cereus and found temperatures ranging from 30 to $37{ }^{\circ} \mathrm{C}$ to be optimum; whereas we did not observe growth in any bacterial strain at a temperature under $4{ }^{\circ} \mathrm{C}$.

Deteriorating sensory properties of milk (odour, clotting, flaking), corresponding with the lipolysis and proteolysis progress, were observed in the samples with non-inactivated spores, stored at $24^{\circ} \mathrm{C}$. Harrigan (1998) described cream flaking caused by lecithinase, consisting of the aggregation of fat spheres after the disintegration of their envelope.

In the samples kept at $4{ }^{\circ} \mathrm{C}$, no sensory changes were found, neither after 3 months of storage, nor in any of the Bacillus cereus strains.

\section{Vliv enzymů Bacillus cereus na kvalitu UHT mléka}

Na modelovém případě kontaminace trvanlivého polotučného mléka spórami 6 kmeny $B$. cereus izolovaných $\mathrm{z}$ prostředí farmy a ze syrového mléka bylo provedeno sledování proteolýzy stanovením změn obsahu bílkovin metodou infračervené spektroskopie, volného tyrosinu Lowryho metodou podle Juffse a stanovení úbytku kaseinových frakcí pomocí SDS-PAGE. Sledování lipolýzy bylo provedeno titračně extrakční metodou. Při skladovací teplotě $4{ }^{\circ} \mathrm{C}$ nebyly enzymatické procesy zaznamenány, zatímco při skladovací teplotě $24^{\circ} \mathrm{C}$ byla zjištěna v průběhu tří týdnů výrazná enzymatická aktivita a smyslové změny UHT mléka. Po 3 týdnech skladování byl stanoven snížený obsah bílkovin z hodnoty $34.55 \mathrm{~g} \cdot 1^{-1}$ až na hodnotu $29.46 \pm 2.00 \mathrm{~g} \cdot 1^{-1}$ mléka, zvýšený obsah volného tyrosinu $\mathrm{z}$ původní hodnoty 0.65 až na $2.13 \pm 0.28 \mathrm{mg} \cdot \mathrm{ml}^{-1}$ a zvýšený látkový obsah volných mastných kyselin z původního obsahu 41.97 na $1617.22 \pm 68.17 \mathrm{mmol} \cdot \mathrm{kg}^{-1}$ mléčného tuku. Po šesti dnech byl zaznamenán úbytek byl $\alpha$-kaseinu na $69.20 \pm 10.21 \%$, $\beta$-kaseinu na $55.96 \pm 15.89 \%$ a $\kappa$-kaseinu na $42.64 \pm 10.44 \%$. Rozsah změn v UHT mléce závisel na kmeni $B$. cereus, výchozím počtu mikroorganismů a zpo̊sobu termoinaktivace spór. 


\section{Acknowledgements}

This study was supported by the grant from the Ministry of Education, Youth and Sports of the Czech Republic No 6215712402 .

\section{References}

BAHOUT AA 2000: Prevalence of Bacillus species in UHT milk. Assoc. Vet Med J 42: 47-53

BOOR KJ, BROWN DP, MURPHY SC, KOZLOWSKI SM, BANDLER DK 1998: Microbiological and chemical quality of raw milk in New York State. J Dairy Sci 81: 1743-1748

BROWN KL 2000: Control of bacterial spores. Brit Med Bull 56: 158-171

BURDOVÁ O, BARANOVÁ M, LAUKOVÁ A, ROZANSKÁ H, ROLA JG 2002: Hygiene of pasteurised milk depending on psychrotrophic microorganisms. Bull Vet Inst Pulawy 46: 325-329

CHAMPAGNE CP, LAINGRR, ROYD, MAFU AA,GRIFFITHS MW 1994: Psychrotrophs in dairy products: Their effects and their control. Crit Rev Food Sci Nutr 34: 1-30

CHRISTIANSSON A, BERTILSSON J, SVENSSON B 1999: Bacillus cereus spores in raw milk: Factors affecting the contamination of milk during the grazing period. J Dairy Sci 82: 305-314

CORZO A, LÓPEZ-FANDINO R, DELGEDO T, RAMOS M, OLANO A 1994: Changes in furosine and proteins of UHT treated milks stored at high ambient temperatures. Lebensm Unters Forsch 198: 302-306

CRIELLY EM, LOGAN NA, ANDERTON A 1994: Studies on the Bacillus flora of milk and milk products. J Appl Bacteriol 77: 256-263

ČSN 570529 1995: Syrové kravské mléko pro mlékárenské ošetření a zpracování. Český normalizační institut, Praha, 8 p.

ČSN 570533 1998: Stanovení látkového obsahu volných mastných kyselin B. Extrakčně titrační metoda stanovení obsahu volných mastných kyselin. Český normalizační institut, 7 p.

DATTA N, DEETH HC 2001: Age gelation of UHT milk - A review. Food Bioprod Process 79: 197-210

DALGLEISH DG 1990: Denaturation and aggregation of serum proteins and casein in heated milk. J Agr Food Chem 38: 1995- 1999

DOGRU M, BAYSAL Z, AYTEKIN C 2001: Suitability of animals' purified milk caseins and their subunit $\kappa$-caseins as substrates for subtilisin and trypsin. Prep Biochem Biotechnol 31: 147-154

GALLAGHER J, KANEKANIAN AD, EVANS EP 1994: Hydrolysis of casein: a comparative study of two proteases and their peptide maps. Int J Food Sci Technol 29: 279-285

HARRIGAN WF 1998: Laboratory Methods in Food Microbiology. Academic Press London, pp. 202-245

HARMON SM, KAUTTER DA 1991: Incidence and growth-potential of Bacillus cereus in ready to serve foods. J Food Protect 54: 372- 374

IPSEN R, OTTE J, LOMHOLT SB, QVIST KB 2000: Standardized reaction times used to describe the mechanism of enzyme-induced gelation in whey protein systems. J Dairy Res 37: 403-413

ISMAIL AA, EFFAT BM, EL-SAMRAGY YA, MAGDOUB MNI 1991: Production of proteases by some dairy psychrotrophic bacteria. Ann Agric Sci 36: 525-534

JOHNSTON DW, BRUCE J 1982: Incidence of thermoduric psychrotrophs in milk produced in the West of Scotland. J Appl Bacteriol 53: 333-337

JUFFS HS 1973: Proteolysis detection in milk. I. Interpretation of tyrosine value data for raw milk supplies in relation to natural variation, bacterial counts and other factors. J Dairy Res 40: 371-381

KELLY AL, FOLEY J 1997: Proteolysis and storage stability of UHT milk as influenced by milk plasmin activity, plasmin/beta-lactoglobulin complexation, plasminogen activation and somatic cell count. Int Dairy $\mathbf{J} 7$ : 411-420

LAEMMLI UK 1970: Cleavage of structural proteins during the assembly of the head of bacteriophage T4. Nature 227: 680-685

LÓPEZ-FANDINO R, OLANO A, CORZO N, RAMOS M 1993: Proteolysis during storage of UHT milk: differences between whole and skim milk. J Dairy Res 60: 339-347

LUKÁŠOVÁ J 1985: The effect of bacterial proteases on milk proteins. Vet Med-Czech 30: 699-703

LUKÁŠOVÁ J, VYHNÁLKOVÁ J, PÁČOVÁ Z 2001: Bacillus species in raw milk and in the farm environment. Milchwissenschaft 56: 609-611

MADSEN JS, QVIST KB 1997: Hydrolysis of milk protein by Bacillus licheniformis protease specific for acidic amino acid residues. J Food Sci 62: 579-582

MARTH EH, STEELE JL 1998: Applied Dairy Microbiology. Marcel Dekker, INC, New York, 516 p.

MATOUŠKOVÁ O, CHALUPA J, CÍGLER M, HRUŠKA K 1992: STAT-Plus uživatelská př́ručka, verze 1.01. Veterinary Research Institute, Brno, CR.

MATTA H, PUNJ V 1999. Isolation and identification of lipolytic, psychrotrophic spore forming bacteria from raw milk. Int J Dairy Technol 52:5 9-62

McMAHON DJ 1996: Age-gelation of UHT milk: Changes that occur during storage on shelf-life and the mechanism by which age-gelation occurs. Heat treatments and alternative methods. International Dairy Federation - Ref. SI 9602, Vienna, Austria, pp. 315-325

MEER RR, BAKER FW, BODYFELT FW, GRIFFITHS MW 1991: Psychrotrophic Bacillus spp. in fluid milk products. A review. J Food Protect 54: 969-979 
MELACHOURIS N, TUCKEY SL 1968: Properties of milk clotting microbial enzyme. J Dairy Sci 51: 650-655

ON 570533 1985: Stanovení látkového obsahu volných mastných kyselin B. Extrakčně titrační metoda stanovení obsahu volných mastných kyselin.

RECIO I, GARCÍA-RISCO MR, RAMOS M, LÓPEZ-FANDIŇO R 2000: Characterization of peptides produced by the action of psychrotrophic proteinases on K-casein. J Dairy Res 67: 625-630

SILVEIRA IA, CARVALHO EP, TEIXEIRA D, BARRIOS BE 1999: Verification of the proteolytic and lipolytic activities of the microbial flora isolated from raw, refrigerated, type B milk. II. Psychrotrophic microorganisms. Rev Lat Am Microbiol 41: 85- 89

SUTHERLAND AD, MURDOCK R 1994: Seasonal occurrence of psychrotrophic Bacillus species in raw milk, and studies on the interactions with mesophilic Bacillus sp. Int J Food Microbiol 21: 279-292

SWAISGOOD HE 1993: Review and update of casein chemistry. J Dairy Sci 76: 3054-3061

VALLEJO-CORDOBA B, MAZORRA-MANZANO MA, GONZALEZ-CORDOVA AF 1998: Determination of short-chain free fatty acids in lipolyzed milk fat by capillary electrophoresis. J Capillary Electrophor 5: 111-114

VLACHOS I, LITOPOULOU-TZANETAKI E 1985: Free fatty acid production by some Bacillus strains grown in UHT milk at room temperature. Milchwissenschaft 40: 521

VYLETĚLOVÁ M, HANUŠ O, URBANOVÁ E, KOPUNECZ P 2000: The occurrence and identification of psychrotrophic bacteria with proteolytic and lipolytic activity in bulk milk samples at storage in primary production conditions. Czech J Anim Sci 45: 373-383

VYLETĚLOVÁ M 2001: Výskyt bakterií rodu Bacillus v syrovém, pasterovaném a UHT mléce. Náš chov 5 : $16-18$

VYLETĚLOVÁ M, HANUŠ O, PÁČOVÁ Z, ROUBAL P, KOPUNECZ P 2001: Frequency of Bacillus bacteria in raw cows' milk and relation to other hygiene parameters. Czech J Anim Sci 46: 260-267

VYLETĚLOVÁ M 2002: Růst Bacillus cereus v pasterovaném mléce při různých skladovacích teplotách. Den mléka. ČZU Praha. pp. 49-50

ZHAO L, QI, J GAO, JA 1998: Kinetics study on the production of alkaline proteinase by Bacillus licheniformis 2709. Chin J Biotechnol 14: 241-247 


\section{Plate V}

Janštová B. et al.: Effect of Bacillus ... pp. 601-609

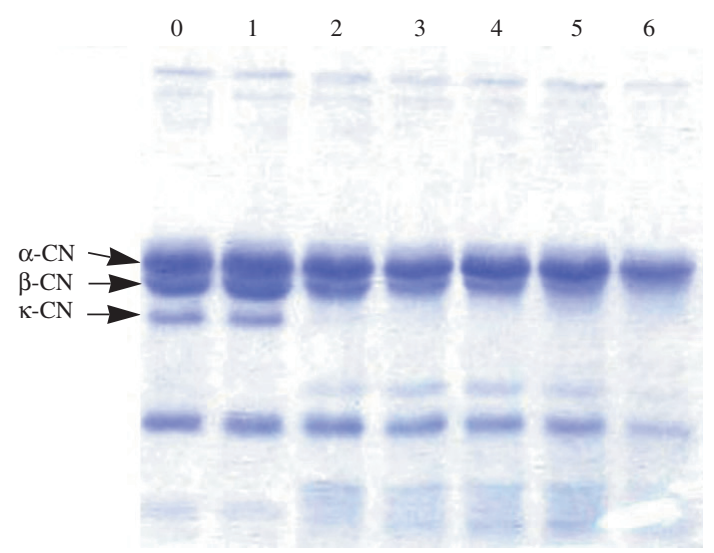

Fig. 3. SDS-PAGE - proteolysis of casein fractions due to the action of Bacillus cereus in milk stored at $24{ }^{\circ} \mathrm{C}$. Figures represent days of storage. 